\title{
Environmental safety of the steppe zone cities within the development of the technique of a «green framework» belt formation
}

\author{
Natalia Yudina ${ }^{1}$, Ekaterina Lysova ${ }^{1,{ }^{*}}$, Oksana Paramonova ${ }^{1}$, and Natalia Samarskaya ${ }^{1}$ \\ ${ }^{1}$ Don State Technical University, 344022, 1, Gagarina sq., Rostov-on-Don, Russia
}

\begin{abstract}
The article is devoted to solving the actual problem of creating a comfortable urban environment in the climatic conditions of the southern cities of Russia. The environmental safety of urban areas in the steppe zone can be ensured by forming belts of the «green belt» of the city, based on the use of specific functions of green spaces. The aim of the work was development of an integrated design method for the «green belt» of the city on the example of the territory of Rostov region, based on the analysis of the urban ecological situation, specificity of the regional range of perennial vegetation with the selection of plants that have environmental tolerance to man-made territory. The proposed technique can be used for other physiographic zones of the territory of the Russian Federation on the basis of selection and ranking of environmental and city-forming criteria for designing the «green belt».
\end{abstract}

\section{Introduction}

Green areas are a tool for creating comfortable living conditions in the cities of the steppe zone of Russia [1,2]. In urban conditions, in addition to traditional ecological functions, perennial green areas perform a number of specific functions affecting climatic, sanitary and hygienic, aesthetic comfort [3,4].

Analysis of the state of urban landscaping in Rostov region revealed predominance of the formation of core elements of the "green belt» in the form of parks, squares and boulevards. However, to create a microclimate within the city under the conditions of the steppe zone is not enough, it is necessary to focus on the development of the territory of urban forests, which are currently in critical condition.

Under the conditions of steppe zone, increase of the «green belt» area at the expense of the territories of urban forests should be based on a scientifically grounded method for selecting the criteria for designing the «green belt» of cities. While ensuring the environmental safety of urban areas, emphasis is placed on a combination of the specific functions of green spaces - climatic, sanitary and hygienic, protective, aesthetic [3].

* Corresponding author: katerina.lysova0803@gmail.com 
Rostov region is located in the steppe zone and is one of the most sparsely wooded regions of the Russian Federation. The territory covered with forests covers 240,000 hectares, which is only $2.5 \%$ of the total area of the region. Among all types of forests in the region, about $70 \%$ are artificial forests, of which only $3.7 \%$ are urban forests located on the lands of urban settlements within the city limits and included, in contrast to mini-parks, parks, etc. in the composition of the forest fund of the country.

The analysis (Fig. 1) showed that for the period from 2009 to 2018 on the territory of Rostov region, urban forests were completely lost in the city of Proletarsk, the area of forests of the city of Taganrog decreased significantly (by $20,97 \%$ ), by $1.13 \%$ - of the city of Kamensk-Shakhtinskiy. The only settlement that increased the area of forests on its territory is the city of Rostov-on-Don (an increase of 271 hectares, or 7,88\%). In general, the area of forests located on the lands of settlements of Rostov region increased only by $1,64 \%[5]$.

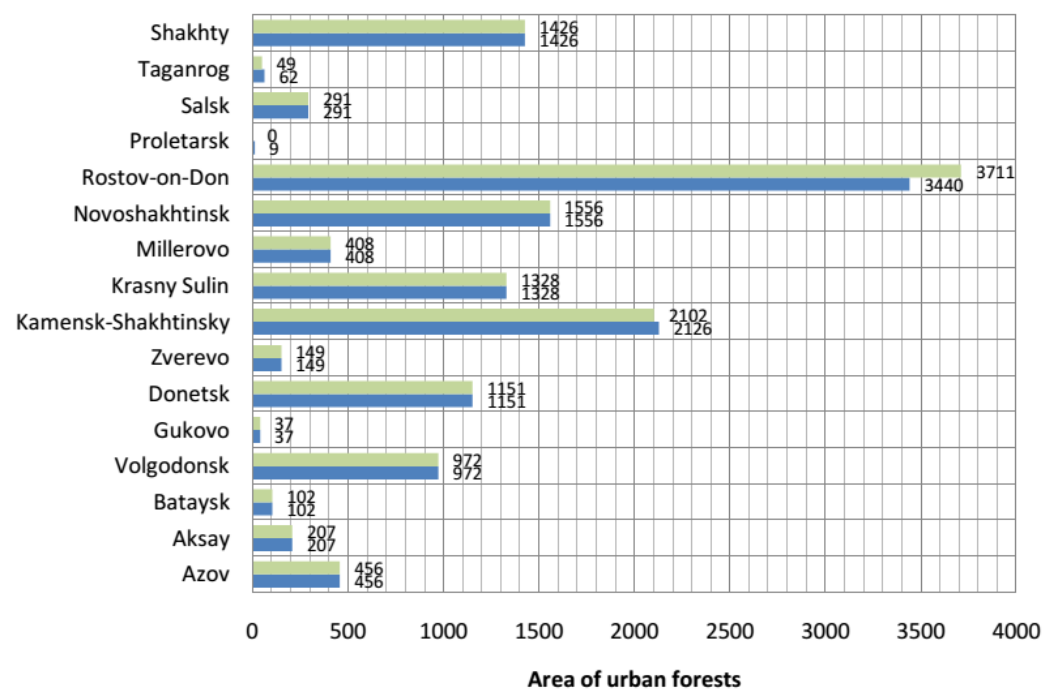

forest area, located on the lands of the settlement, hectares, 2018

forest area, located on the lands of the settlement, hectares, 2009

Fig. 1. Distribution of the urban forests area located on the lands of the settlements of Rostov region, and their relation to the indicators of the previous forest plan [5].

Urban forests of Rostov region practically do not implement the wood material function, but perform protective, sanitary and climatic functions (protect land from wind and water erosion, help to mitigate the effects of dry winds, droughts and dust storms, air purification, etc.).

The first artificial forest massifs were laid at the beginning of the 20th century to prevent moving sand and to protect against wind and wind erosion. To date replanting of young trees and shrubs is practically not conducted, urban forests are rapidly aging. Reducing the life expectancy of tree plantations under conditions of increasing anthropogenic load, low self-healing ability in a short time can lead to a critical reduction in the area of urban forests. Considering the functions performed by urban forests, the result may be a change in the meso- and microclimate of the territories (temperature increase, decrease in air humidity), increase in the level of air pollution due to increase in dust load, etc. Thus, while ensuring environmental safety of urban areas, one should take into account the maximum use of the climatic, sanitary and hygienic, protective functions of green 
space. The choice of plants in this case should be based on a scientifically-based method of forming a «green belt» around large cities under the conditions of steppe zone.

The design of continuous «green belt» belts in the cities of the steppe zone should be based on landscape-territorial specificity, flat terrain, and a high degree of agricultural development of the territories. The increase in artificial forest plantations within urban areas is the only way to change the meso- and microclimate by adjusting the parameters of evaporation, airflow and humidity. The design of green belts can be based on the following principles: continuity in the form of using the existing landscaping of territories, continuity to ensure the ecological functioning of the «green belt» [6-12]. The principle of relative optimality will be used in environmental quality management through the optimal combination of species composition of tree-shrub vegetation with dust and gas resistance [13-15].

\section{Objective and tasks of research}

The object of the study was urban forests (climax ecosystem) on the territory of the land of Salsk urban settlement (steppe region of the European part of the Russian Federation, steppe zone).

\section{Research methods}

To assess the state of the urban forest, generally accepted methods of botanical research and inventory of forest quarters were used based on reconnaissance exits in 2018 and a visual assessment of the ecological status of perennial vegetation by species within the boundaries of test plots (size of sites $30 \times 30 \mathrm{~m}, 22 \times 50 \mathrm{~m}$ ), and methods of forest valuation. Analysis of the natural regeneration of the forest was carried out on trial plots of $10 \times 10 \mathrm{~m}$ diagonally within the boundaries of trial plots [16]. The assessment of the ecological state of the stand of urban forest was carried out according to the method of V.A. Alekseev.

\section{Results of the study}

The studied urban forest is located in the northeast of the city of Salsk, block 24, a deciduous forest, type of planting - natural boundaries. From the south-east the territory adjoins the residential building. The main tree species of the urban forest of the city of Salsk are: Chinese elm (Ulmus parvifolia), black locust (Robínia pseudoacácia), Norway maple (Ácer platanoídes), English oak (Quércus róbur), White birch (Bétula péndula), European ash (Fráxinus excélsior), Sophora japanica (Styphnolóbium japónicum), honey locust (Gleditsia triacanthos). Undergrowth - bloody dogwood (Córnus álba), Tatarian maple (Ácer tatáricum). The average age of the forest at the time of the study was 60-77 years according to the measurement of stem diameters (Table 1), namely Chinese elm (Ulmus parvifolia) is 77 years old, black locust (Robínia pseudoacácia) is 70 years old, European ash (Fráxinus excélsior) is 70 years.

With a continuous recalculation on trial plots, dominant types of woody vegetation were identified (Fig. 2).

Table 1. Determination of the age of perennial plantations by stem diameter in the city forest quarter No. 24 of the city of Salsk. 


\begin{tabular}{|c|c|c|c|c|c|c|c|}
\hline $\begin{array}{c}\text { Trial site } \\
\text { number }\end{array}$ & Type of tree species & \multicolumn{4}{|c|}{ Diameter of trees, cm } & $\begin{array}{c}\text { Average diameter } \\
\text { of trees, cm }\end{array}$ \\
\hline 1 & Ulmus parvifolia & 22 & 20 & 21 & 22 & 20 & 21 \\
\hline 2 & Robínia pseudoacácia & 10 & 26 & 15 & 11 & 20 & 16,4 \\
\hline 3 & Fráxinus excélsior & 14 & 17 & 18 & 18 & 17 & 16,8 \\
\hline
\end{tabular}

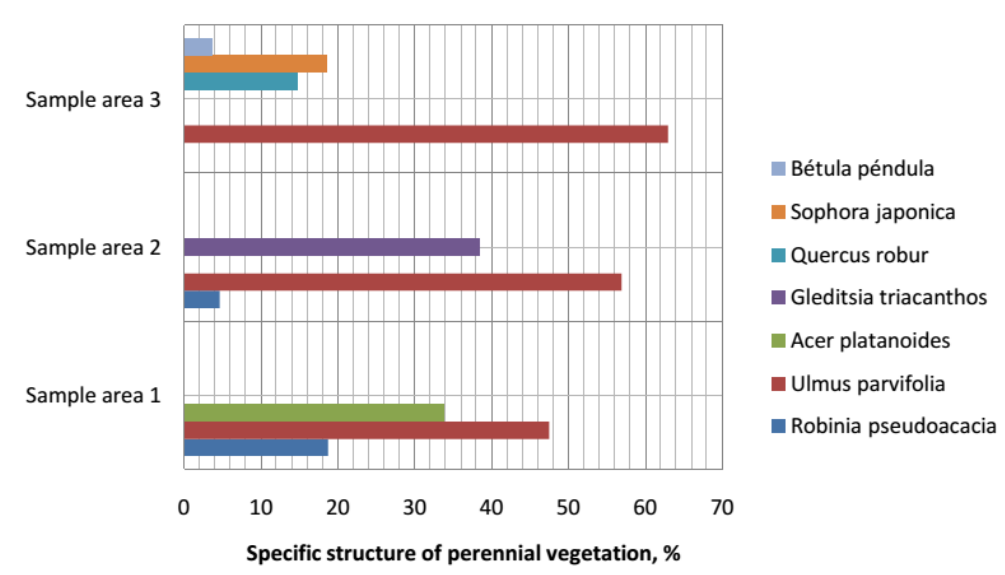

Fig. 2. Species composition of perennial vegetation in the city forest quarter No. 24 of the city of Salsk.

The value of the coefficient of the stand of the urban forest on the lands of Salsk urban settlement on the trial plots ranged from 2 to 3.5 points out of 5 possible. A visual inspection of the trees revealed damage in the form of cracking of the bark. The average distance between the trees at the registration sites was $6.2 \mathrm{~m}$, on one hectare there were 300 trees. Based on the standards of taxation of forests in the steppe zone forests with less than 800 trees per 1 hectare are considered unsatisfactory.

An assessment of the natural renewability of forests (Table 2) revealed an unsatisfactory rate of renewal, based on standards of 3,000 pieces per 1 hectare of forest-forming species.

Table 2. Results of counting natural forest regeneration on trial plots.

\begin{tabular}{|c|c|c|c|c|c|}
\hline \multirow{2}{*}{ Type of tree species } & \multicolumn{5}{|c|}{ Calculation of natural renewal on 100 m 2 (pieces) } \\
\cline { 2 - 6 } & $\begin{array}{c}\text { Trial site } \\
\text { number 1 }\end{array}$ & $\begin{array}{c}\text { Trial site } \\
\text { number 2 }\end{array}$ & $\begin{array}{c}\text { Trial site } \\
\text { number 3 }\end{array}$ & $\begin{array}{c}\text { Trial site } \\
\text { number 4 }\end{array}$ & $\begin{array}{c}\text { Trial site } \\
\text { number 5 }\end{array}$ \\
\hline Fráxinus excélsior & 11 & 9 & 8 & 9 & 10 \\
\hline Robínia pseudoacácia & 5 & 7 & 7 & 5 & 4 \\
\hline Ácer platanoídes & 4 & 4 & 5 & 6 & 6 \\
\hline In total: & $\mathbf{2 0}$ & $\mathbf{1 8}$ & $\mathbf{2 1}$ & $\mathbf{1 8}$ & $\mathbf{2 0}$ \\
\hline
\end{tabular}

The analysis of data on the assessment of natural renewability of the forests of the steppe zone reflects the unfavorable, often critical situation in most urban forests of large cities of Rostov region. Preservation and multiplication of the area of the «green belt» must be properly organized, it is imperative to take into account the specific functions of green spaces [3] and, therefore, it requires the development of methods for forming the "green belt» of large cities in the steppe zone.

The methodology (Fig. 3) should be based on a deep situational analysis of a specific gradoecological situation, including botanical inventory and monitoring of the status of existing perennial plantations, and an assessment of the anthropogenic load on environmental components.

The main stage of the implementation of the methodology is the formation of a «green 
belt» - it involves selection of a regional assortment of perennial vegetation within which plants are selected that are tolerant to the anthropogenic load of the territory and ensure implementation of specified functions. The final stage is reduced to the design of planting urban forests, taking into account the principles of sustainable development of territories. At all stages of the implementation of the methodology, regular botanical monitoring of perennial plantings is carried out.

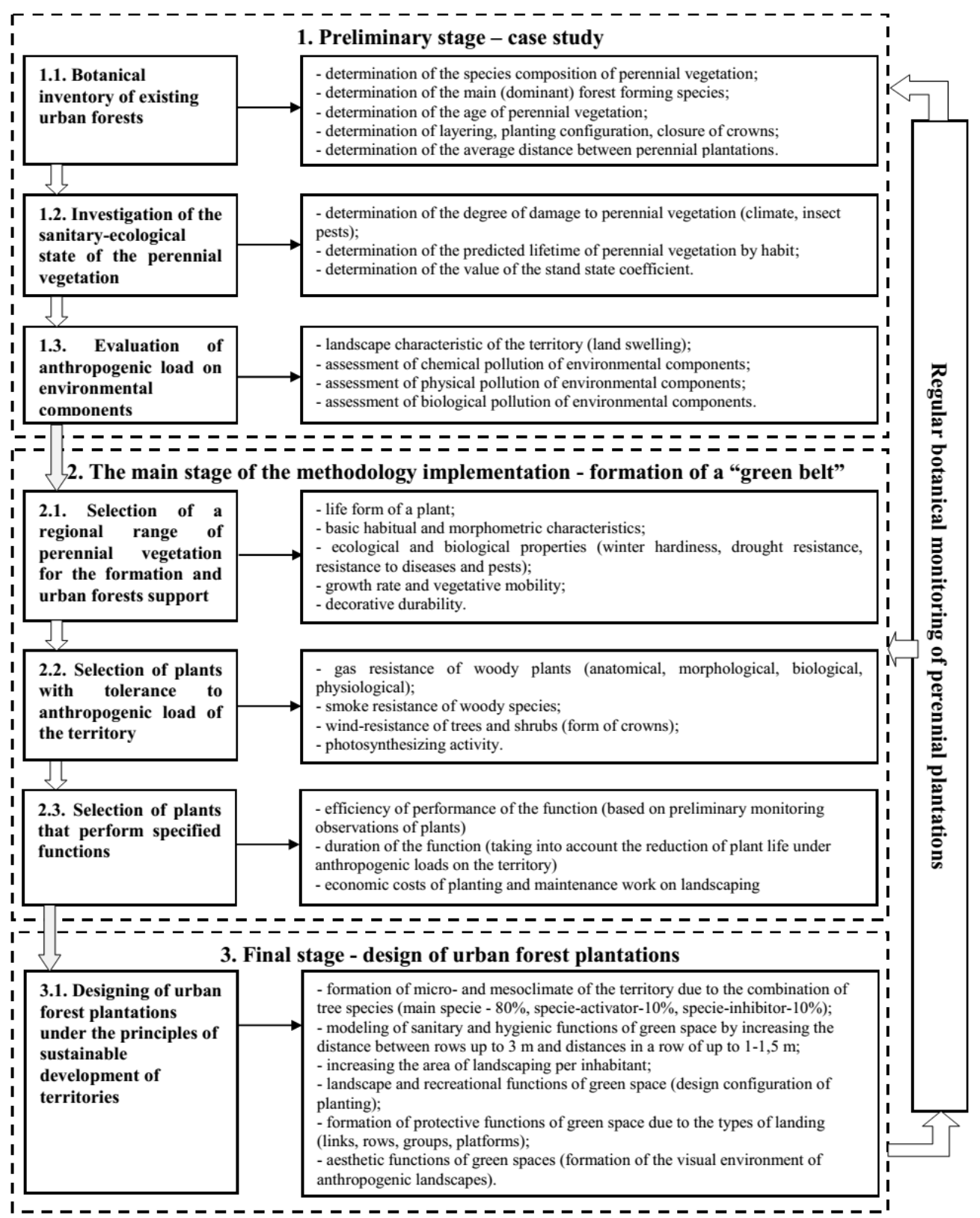

Fig. 3. Method of forming the «green belt» of cities of the steppe zone. 


\section{Discussion and conclusions}

The urban forests of the steppe zone of Rostov region cease to perform the most important ecological functions in order to ensure a comfortable and healthy living environment in large cities. At the same time, there is no single approach to systematically solving the problem of building a «green belt» in our country. The analysis of foreign and domestic experience made it possible to study the advantages and disadvantages of the existing methodological approaches to the formation of «green belts» of large cities, systematize their most important criteria and apply them to cities of the steppe zone (using the example of urban forests of Rostov region). The next stage of our research will be the selection and ranking of the criteria for the formation of a «green belt» for cities in the steppe zone.

\section{References}

1. N. A. Narbut, Mat. Int. Conf. «InterCarto/InterGis», 21, 119-123 (2016)

2. I. M. Gheorghita, Yaroslavl pedagogical Bulletin, 2(3), 133-136 (2011)

3. I. A. Ilchenko, Bull. Tagan. Inst. Manag. Econ., 1(19), 37-42 (2014)

4. I. V. Sanaev, Fores. Bull., 6, 71-76 (2006)

5. Amati, Marco, ed., Urban green belts in the twenty-first century (2016)

6. U. Riecken, K. Ullrich, A. Lang, UK, IUCN, 3-10 (2006)

7. Boyer-Rechlin, Bethany, Scand. J. For. Res., 25 (9), 69-72 (2010)

8. Schneider-Jacoby, G.Martin, Schwaderer, W. Fremuth, The Green Belt of Europe: from vision to reality (2006)

9. K.H. Peng, Y.C. Kuo, H.Y. Lin, Int. Rev. Spat. Plan. Sust. Develop., 1(3), 5-16 (2015)

10. M. Gagliano, In a green frame of mind: perspectives on the behavioural ecology and cognitive nature of plants (2015)

11. Reeder, A. David, The Europ. Cit. Gr. Spa., 54-64 (2016)

12. A. V. Pogorelov, et al., Regional geographical studies, 119-137 (2017)

13. A. Ya.Grigoriev, O. S. Lisova, Scie. Dial., 2, 100-111 (2012)

14. S. A. Matovnikov, et al., Bull. Volg. St. Un. Arch. Ci. Eng., 36, 248-257 (2014)

15. D. A. Shlyakhova, I. P. Kirienko, Vis. Cul.: Des., Adve., Infor. Techn., 47- 50 (2018)

16. I. F. Korostelev, Basic research in forestry (2011) 